18. Perri GD, Cadeo GP, Castelli F, et al Transmission of HIVassociated tuberculosis to health-care workers. Lancet $1992 ; 340 ; 682$

19. Centers for Disease Control and Prevention. Probable transmission of multidrug-resistant tuberculosis in a correctional facility--California. MMWR 1993;42:48-51.

20. Onorato I. Tuberculosis in the United States. Multiple drugresistant TB in the US. In: National Workshop on Tuberculosis, HIV and O ther Emerging Issues. Ottawa, ON: Health Canada; May 3-5, 1993:2-3.

21. Styblo K. The estimation of the annual risk of tuberculosis infection. Bull Int U nion Tuberc 1978;51(suppl):1-101.

22. Becker H. An 'outbreak' of tuberculin converters in a residential care facility. Geriatric Medicine Quarterly 1989;3:179,188,190191,194-195,203.

23. Jereb JA, Elevens RM, Privett TD, et al. Tuberculosis in health care workers at a hospital with an outbreak of multidrugresistant Mycobacterium tuberculosis. Arch Intern Med 1995;155: 854-859.

24. Berman J, Levin ML, Tangerose S, Desi L. Tuberculosis risk for hospital employees: analysis of a five-year tuberculin skintesting program. Am J Public Health 1981;71:1217-1222.

25. Faden HS, Lee J, Ogra PL. Employee health screening in pediatric hospital. NY State J Med 1979;79:1708-1711.
26. Statistics Canada. Tuberculosis Statistics, 1992. Ottawa, ON: Statistics Canada; 1994 (Catalogue no. 82-220).

27. Ontario Ministry of Health. Epidemiology of tuberculosis in Ontario, 1989-1992. Public Health and Epidemiology Report. Public Health Branch, Ontario Ministry of Health; 1994;5(3):63-72.

28. Bailey TC, Fraser VJ, Spitznagel EL, Dunagan WC. Risk factors for a positive tuberculin skin test among employees of an urban, midwestern teaching hospital. Ann Intern Med 1995:122:580-585

29. Moline JM, Markowitz SB. Medical surveillance for workers exposed to tuberculosis. Occup M ed 1994:9(4):695-721.

30. Ada1 KA, Anglim AM, Palumbo CL, Titus MG, Coyner BJ, Farr $\mathrm{BM}$. The use of high-efficiency particulate respirators to protect hospital workers from tuberculosis: a cost-effectiveness analysis. N Engl J Med 1994;331:169-173.

31. Nettleman MD, Fredrickson M, Good NL, Hunter SA. Tuberculosis control strategies: the cost of particulate respirators. Ann Intern Med 1994;121:37-40.

32. Fanning EA, Menzies R. Surveillance of medical students for TB urged. Can Med Assoc J 1995;152:328. Letter.

\title{
Fluoroquinolone for $E$ coli in Poultry
}

\section{by Gina Pugliese, RN, M S Medical News E ditor}

The US Food and Drug Administration (FDA) has approved a watersoluble form of sarafloxacin hydrochloride for the treatment of Escherichia coli infections in flocks of chickens and turkeys raised for food.
This is the first time any fluoroquinolone has been approved for animal use in the United States. The FDA is limiting distribution to areas of the country with intensive poultry farming.

The Centers for Disease Control and Prevention will add antibiotic susceptibility testing to its surveillance of
E coli 0157:H7 and Salmonella in five states. If fluoroquinolone-resistant bacteria arise, a federal interagency group will oversee the use of molecular methods to trace the origins and spread of the resistant bacteria.

FROM: Gough M. FDA ap proves fluoroquinolone for use in poultry. Lancet 1995;346:960. 